sciendo Порівняльна професійна педагогіка 9(1)/2019 Comparative Professional Pedagogy 9(1)/2019

DOI: $10.2478 /$ rpp-2019-0004

$\mathrm{PhD}$ in Pedagogy, Associate Professor, OLESIA SADOVETS

Khmelnytskyi National University Address: 11 Instytutska St., Khmelnytskyi, 29016, Ukraine

E-mail: lesyasadovets@gmail.com

\title{
ACADEMIC ENGLISH AS A COMPONENT OF CURRICULUM FOR ESL STUDENTS (FOREIGN EXPERIENCE)
}

\begin{abstract}
It has been substantiated that Academic English must be an integral component of ESL students' study at foreign languages departments to achieve success as professionals and be ready to realize themselves in a demanding world of today. We have defined the main problem on the way to it, namely the insufficient provision of the Academic English discipline in curricula of foreign language departments or its absence. The necessity to elaborate a syllabus for Academic English discipline being tanght throughout all the course of study has been substantiated. Educational programs of Academic English in a number of foreign educational establishments of Great Britain, the USA, Canada and Australia have been analyzed and their defining features have been outlined. Strategies and conditions for effective teaching of Academic English have been characterized. It has been defined that in general, in spite of slight differences in the topics covered by different EAP programs, all of them are aimed at: developing strategies and vocabulary for reading and understanding academic texts; finding, understanding, describing and evaluating information for academic purposes; developing active listening and effective note-taking skills; building on language skills to describe problems and cause-and-effect; gathering a range of information, using the skills learned, to integrate it into a written report; engaging in peerto-peer feedback before finalising one's piece of academic work. Requirements for students' achievements at the end of the course have been determined. As a basis for Academic English syllabus elaboration has been chosen a course by M. Hewings and C. Thaine (upper-intermediate and advanced levels). On its basis we have defined units to be covered by the course as well as skills to be developed. Recommendations as to better and more efficient teaching of the discipline have been outlined.

Keywords: Academic English, curriculum, syllabus, ESL students, foreign language department.

\section{АНОТАЦІЯ}

Обгрунтовано важливість дисиипліни «Академічна англійська мова» як невід 'ємного компоненту навчання студентів на спеціальностях іноземної філології для досягнення ними професійної досконалості та реалізації себе на вимогливому ринку прачі. Було визначено основну перешкоду на шляху до изього - недостатній рівень вивчення дисчипліни «Академічна англійська мова» на спечіальностях іноземної філології або їі відсутність у навчальному плані. Обгрунтовано необхідність розробки навчальної програми з «Академічної англійської мови» для усіх курсів навчання. Проаналізовано навчальні програми з «Академічної англійської мови» у низиі зарубіжних ЗВО Великої Британії, США, Канади, Австралї та визначено їх характерні особливості, стратегії
\end{abstract}


sciendo Порівняльна професійна педагогіка 9(1)/2019 Comparative Professional Pedagogy 9(1)/2019

та умови ефективного викладання. Зясовано, що, незважаючи на незначні відмінності у темах, які передбачені програмами $з$ «Академічної англійської мови» у провідних закладах освіти згаданих країн, усі вони спрямовані на: поглиблення знання спеціалізованої лексики для читання та розуміння академічних текстів; знаходження, опрацювання та використання академічної інформації; розвиток навичок активного слухання та занотовування; розвиток лексичних навичок для опису проблеми, ї̈ причин та наслідків; збирання інформачії для підготовки доповіді; використання групової та індивідуальної роботи студентів для удосконалення навичок академічного письма. Визначено вимоги до знань та вмінь студентів по закінченню курсу вивчення «Академічної англійської мови». Основою для розробки навчальної програми з дисципліни «Академічна англійська мова» став курс, розроблений на базі Кембріджського університету для рівня знання мови вище середнього (для молодших курсів) та поглибленого (для старших курсів). Було визначено розділи (тематику) для вивчення та навички, які мають бути сформовані. Окреслено рекомендачії щзодо ефективного викладання дисципліни для студентів філологічних спеціальностей, які вивчають англійську мову як іноземну.

Ключові слова: академічна англійська, навчальний план, навчальна програма, студенти, які вивчають англійську мову як іноземну, спеиіальності іноземної філології.

\section{INTRODUCTION}

Nowadays, foreign language knowledge, especially English, is a must for every educated person who is eager to get a well-paid job and have good career prospects. Modern higher educational system providing education in foreign language specialties ("Translation", "Applied Linguistics") for ESL students must organize students' training according to the demands of modern life. Students of the mentioned specialties must have good command not only of general (standard) English, but of academic English to be a competent specialist in their branch and be able to continue their education pursuit in postgraduate courses.

Unfortunately, ESL students often fall into the conversational English usage category. Many of them have been taught for several years in foreign language departments, yet they still display striking deficiencies in reading and writing in academic contexts. The situation is very frustrating because there is clear evidence that some educators are still unaware of what academic English is and the situational obstacles related to it (Wong, \& Snow, 2000; Ferris, 2002)

Thus, it is clear that if students want to achieve socio-economic success, it is imperative that they are able to perform at the appropriate academic level. And performing at this level can be a continuing struggle, since academic English entails "multiple complex features of English required for long-term success in studying, completion of higher education, and employment with opportunity for professional advancement and financial rewards" (Rumberger, \& Scarcella, 2001).

The need to emphasize approaches that target the instruction of academic English is more important than ever. According to R. Scarcella, academic English is "needed to challenge the tenets of those in power who use it ... without knowledge of academic English, individuals may be excluded form participation in educated society and prevented from transforming it" (Scarcella, 2003).

This situation is peculiar to many countries of the world where ESL students undergo training in foreign language departments, but we have concentrated our research on Ukraine. Profound analysis of curricula at a number of home universities testifies that 
only a few of them include the discipline of Academic English into their curriculum, others have either Academic Reading or Academic Writing only, while the majority of universities don't include Academic English into their curriculum at all. Besides, those that have it in their course of studying usually have it taught only at senior years (year) of studying, thus not encompassing all the volume of academic knowledge. Such a situation makes it necessary to reconsider prospects of including Academic English discipline into the curriculum of foreign language departments.

\section{THE AIM OF THE STUDY}

The main idea of the article is to raise the issue of necessity to include the discipline of Academic English into the curriculum of universities training ESL students at foreign language departments and outline recommendations as to the relevant content of the discipline, its teaching methods, as well as elaboration of the syllabus.

\section{THEORETICAL FRAMEWORK AND RESEARCH METHODS}

In the course of research, we have studied and analyzed a lot of scientific works dedicated to theoretical and practical issues of Academic English teaching. Of special interest are works of T. Finley (2014) (strategies of Academic English teaching), M. Hewings (2012) (practical course of Academic English), R. Morzano (2001) (practical aspects of Academic English learning), R. Scarcella (2003) (conceptual framework). We have also thoroughly studied a number of Academic English courses at British, American, Canadian and Australian universities (University of Richmond, University of California, Cambridge University etc.). Having analyzed the publications and research papers of the above mentioned scientists, documents and materials of international organizations and the practice of Academic English teaching to ESL students, we have carried out our own research concerning prospects of including Academic English into the curricula of Ukrainian universities (foreign language departments) and suggestions as to the content of the discipline syllabus (units to be studied).

To conduct the research, we have used a range of general scientific methods (including study and analysis of reference, scientific educational print and on-line sources), as well as comparative method, systematization and generalization. Our research is qualitative (descriptive) and includes observation, document analysis, narrative inquiry.

\section{RESULTS}

In scientific literature there are a lot of definitions of academic language. Having analyzed a great number of them we consider it substantial to outline those which, to our mind, completely encompass the meaning of this notion. According to Education Glossary academic language refers to the oral, written, auditory, and visual language proficiency required to learn effectively in universities and academic programs. i.e., it's the language used in lectures, seminars, books, and journals. It's the language that students are expected to learn and achieve fluency in (Academic English, 2017).

According to Csun academic language is the language needed by students to do the work in universities. It includes, for example, discipline-specific vocabulary, grammar and punctuation, and applications of rhetorical conventions and devices that are typical for a content area (e.g., essays, lab reports, discussions of a controversial issue) (The Sourcebook for Teaching Science, 2017).

Academic language is the language needed by students to understand and communicate in the academic disciplines. It includes such things as specialized vocabulary, conventional text structures within a field such essays and lab reports and other languagerelated activities typical of classrooms, such as expressing disagreement, discussing an 
sciendo Порівняльна професійна педагогіка 9(1)/2019 Comparative Professional Pedagogy 9(1)/2019

issue, or asking for clarification. Academic language includes both productive and receptive modalities (Academic English, 2017).

Having considered peculiarities of academic English, we have made a conclusion that it not only includes several dimensions of knowledge, but also emphasizes the context where learning takes place. Educators need to be aware of all these dynamics in order to teach ESL students effectively and help them develop necessary skills to succeed in life and become productive members of society. Those dimensions of knowledge are:

- linguistic dimension (includes the following areas: phonological, lexical, grammatical, sociolinguistics, and discourse);

- cognitive dimension (includes critical literacy, cognitive and metalinguistic strategies);

- sociocultural/psychological dimension (social and cultural norms, beliefs, values, attitudes, motivations, interests, behaviors, practices, and habits are involved in this dimension; they grow, take shape, and change in the larger social context where academic English happens) (Scarcella, 2003).

Scientists and researchers, as well as educators, dedicate a lot of their works to defining strategies necessary to teach Academic English to ESL students. They stress that academic language is a meta-language that helps learners acquire at least 50,000 words they are expected to have internalized by the end of study and includes everything from illustration and chart literacy to speaking, grammar and genres within fields. We should think of academic language as the verbal clothing that we do in classrooms and other formal contexts to demonstrate cognition within cultures and to signal graduation readiness.

Todd Finley, PhD, a tenured professor of English Education at East Carolina University, defined eight strategies of teaching effective academic English (Finley, 2014):

1. Encouraging students to read diverse texts. Reading and then thinking and talking about different genres is a robust sequence for learning academic language.

2. Introducing summary frames. Summarizing is a simple and fail-safe approach to academic language activities. Students read a section of text to themselves before verbally summarizing the passage to a partner. Alternatively, learners can complete sentence frames or guides for summarization.

3. Translation from academic to social language (and back). Teachers should model how to say something in a more academic way or how to paraphrase academic texts into more conversational language, provide students with a difficult expository passage and have teams reinterpret the text using everyday language.

4. Completion of scripts of academic routines. Some discourse routines seem obvious to adults, but are more complex to junior students unless they are provided with scaffolding, like these speech examples: "The topic of my presentation is "; "In the first part, I give a few basic definitions. In the next section, I will explain ___ . In part three, I am going to show

5. Dynamic introduction of academic vocabulary. Repeated encounters with a word in various authentic contexts can help students internalize the definition.

6. Using a diagram with similarities and differences. When students generate a list of similarities and differences between words and complete a Venn diagram, comparing and contrasting two objects or processes or whatever (Venn diagrams can be used to compare information about two things, organise similarities and differences), they work with one of Robert Marzano's high-yield instructional strategies. Marzano's strategies provide an excellent resource to improve student capacity for learning. They are: 1) identifying similarities and differences; 2) summarizing and note-taking; 3) reinforcing effort and providing 
recognition; 4) homework and practice; 5) non-linguistic representations; 6) cooperative learning; 7) setting objectives and providing feedback; 8) generating and testing hypothesis; 9) questions, cues, and advance organizers (Morzano, 2001).

7. Writing with a transition handout. Formal academic writing challenges students of all ages. Before students write, they should be given a handout of transitions (transitions describe relationships between ideas, they can work well with enough context in a sentence or paragraph to make the relationships clear; transition words are those of illustration, contrast, addition, time, space, concession, similarity or comparison, emphasis, details, examples, consequence or result, summary, suggestion). (University of Richmond Writing Center, 2017). Teachers should model where transitions fit, and describe how they help the reader.

8. Teaching key words for understanding standardized test prompts. Kechia Williams teaches 10 terms that help students understand prompts and ace standardized tests. They are: analyze, persuade (argue, convince), compare, contrast, summarize, demonstrate, describe, explain, interpret, infer. For example, if a student can analyze, interpreting should not be a problem. Also comparing and contrasting go hand in hand, but they are not always connected. The terms are also cross-curricular, and that makes them extremely useful in all classes (Williams, 2018).

We have also analyzed educational programs of Academic English in a number of foreign educational establishments of Great Britain, the USA, Canada and Australia. Thus, the University of Newcastle (Australia) offers a course of Academic English for ESL students that focuses on academic language, practices and provides assistance with navigating university culture as well as an opportunity to build connections with other students. The course focuses on a number of areas related to the English language and literacies and provides hands-on experience in areas, such as: university email; using blackboard; language, e.g. grammar, academic vocabulary and voice; looking at different types of academic texts; using the library; finding your voice in tutorials; synthesising information, e.g. summarising, paraphrasing and paragraphing; reading academic material; referencing; listening to lectures to practice note-taking; becoming familiar with learning spaces at the university (The University of Newcastle, 2018).

To achieve success in teaching Academic English to ESL students the following conditions are necessary (FluentU, 2018):

- using authentic materials (articles that come from newspapers rather than ESL sites);

- using authentic classroom materials (when choosing material for EAP classes, such as textbooks, those that are not designed for ESL students shuld be chosen, that is, not written or developed for language studies);

- using real college lectures in class;

- giving assignments similar to those students will receive in academic environment (research papers, projects);

- letting students direct their own learning (giving students some freedom to set their own educational goals; educators might have them decide what topics should be covered in class, what types of assignments they'll do or how they'll study to accomplish those assignments).

While organizing the course of Academic English educators should keep in mind that four components of language learning must be fulfilled in the process of teaching: listening, speaking, reading and writing. These skills can be developed using tasks, such as listening to lectures, taking notes, making presentations, reading academic texts (including long sentences and visual information) and writing reports using proper academic words. 
sciendo Порівняльна професійна педагогіка 9(1)/2019 Comparative Professional Pedagogy 9(1)/2019

Throughout the course there must be provided opportunities to share students' practice work with other learners, to give and get feedback.

In general, in spite of slight differences in the topics covered by different EAP programs, all of them are aimed at:

- developing strategies and vocabulary for reading and understanding academic texts;

- finding, understanding, describing and evaluating information for academic purposes;

- developing active listening and effective note-taking skills;

- building on language skills to describe problems and cause-and-effect;

- gathering a range of information, using the skills learned, to integrate it into a written report;

- engaging in peer-to-peer feedback before finalising their piece of academic work.

Having generalized a number of educational programs in Academic English, we have made some recommendations as to the elaboration of the corresponding program (discipline) in Ukrainian universities, providing training of ESL students in foreign language departments, starting from the first year of study to the last one. In this respect a Cambridge English integrated skills course for EAP students is of special interest. Having analyzed the course of Academic English elaborated by Martin Hewings and Craig Thaine (for levels from Intermediate to Advanced) and the level of ESL students at foreign language departments at Ukrainian universities, we consider it appropriate to elaborate a syllabus for the discipline of Academic English on the basis of this course with the upper intermediate level for junior students (years 1-3) and advanced level for senior students (years 4-5) (Hewings, 2012; Hewings, \& Thaine, 2012).

Level B2 is aimed at students who will soon be starting undergraduate or postgraduate studies and are independent users at level B2 and above. Level $\mathrm{C} 1$ is aimed at students who may already have begun their academic studies.

The student's book of the mentioned course is organised into integrated skills and lecture skills units. Ten units are organised around a broad topic of interest and help students develop skills in reading, speaking, listening and writing academic English. Each of these units ends with a Grammar and Vocabulary Focus that is of particular importance in academic written and spoken communication. The Cross References in the margins point to further information, strategies, or extra practice which can be found in the Grammar and Vocabulary section of that unit. After every two integrated skills units there is a Lecture Skills Unit to help students develop skills in listening to lectures and taking notes. For this course, a variety of lectures were recorded at the University of Cambridge. Extracts from these lectures have been used in the Lecture Skills units to help you understand, for example, how lecturers use language, visual information, gesture and pronunciation to present content and show how they are organising the lecture. These units help students to think about the content of lectures, understand new terms, tutor's instructions, vocabulary to the context, and work with listening (in gist and in detail, taking notes and understaning the main point).

Cambridge Academic English course uses authentic academic texts. They may be challenging at first but students will learn strategies in the course to cope with them. The vocabulary focused on in the course has been selected for being of particular importance in academic writing, reading, lectures and seminars. The Word List elaborated for the course covers key academic words essential for the development of academic vocabulary.

To make sure that the language taught in the course is up-to-date and relevant, the authors have made extensive use of the Cambridge Academic English Corpus (CAEC) in preparing the material. The CAEC is a 400 -million-word resource comprising two parts. 
One is a collection of written academic language taken from textbooks and journals written in both British and American English. The second is a collection of spoken language from academic lectures and seminars. In both parts of the corpus a wide variety of academic subject areas is covered. Using these corpora has allowed the authors to learn more about academic language in use, and also about the common errors made by students when using academic English. With this information one can be sure that the material in this course is built on sound evidence of how English is used in a wide variety of academic contexts. CAEC provides authentic examples in the activities of how language is used, and gives useful facts about how often and in what contexts certain words and phrases are used in academic writing.

Having studied the structure and the content of the course of Academic English by M. Hewings and C. Thaine (Hewings, 2012; Hewings \& Thaine, 2012) we have compiled a suggested list of topics to be covered in a corresponding course of Academic English for ESL students at Ukrainian universities (foreign language departments) and skills to be developed. Thus, topics to be covered in years 1-3 should include (table 1):

Table 1

Topics of Academic English to be covered in junior years of ESL students' study and skills to be developed

\begin{tabular}{|c|c|c|c|}
\hline Topics & Reading skills & $\begin{array}{l}\text { Listening and } \\
\text { speaking skills }\end{array}$ & Writing skills \\
\hline 1 & 2 & 3 & 4 \\
\hline $\begin{array}{l}\text { Choices and } \\
\text { implications }\end{array}$ & $\begin{array}{l}\text { Researching texts for essays. } \\
\text { Skimming and scanning. } \\
\text { Identifying the sequence } \\
\text { of ideas }\end{array}$ & $\begin{array}{l}\text { Introducing } \\
\text { your presentation. } \\
\text { Clarifying } \\
\text { key terms }\end{array}$ & $\begin{array}{l}\text { Understanding how essay } \\
\text { types are organized. Drafting } \\
\text { the introduction to an essay }\end{array}$ \\
\hline $\begin{array}{l}\text { Risks } \\
\text { and hazards }\end{array}$ & $\begin{array}{l}\text { Selecting and prioritising } \\
\text { what you read. Thinking } \\
\text { about what you already } \\
\text { know. Inferring the meaning } \\
\text { of words }\end{array}$ & $\begin{array}{l}\text { Preparing slides } \\
\text { for presentations. } \\
\text { Choosing the right } \\
\text { type of chart for } \\
\text { a slide. Presenting } \\
\text { charts }\end{array}$ & $\begin{array}{l}\text { Using claims to plan essays. } \\
\text { Supporting claims } \\
\text { with evidence }\end{array}$ \\
\hline $\begin{array}{l}\text { Language and } \\
\text { communication }\end{array}$ & $\begin{array}{l}\text { Predicting the content } \\
\text { of a text. } \\
\text { Reading for detail. Scanning } \\
\text { for information. } \\
\text { Understanding implicit } \\
\text { meanings }\end{array}$ & $\begin{array}{l}\text { Making } \\
\text { suggestions } \\
\text { in group work }\end{array}$ & $\begin{array}{l}\text { Referring to other people's } \\
\text { work }\end{array}$ \\
\hline $\begin{array}{l}\text { Difference } \\
\text { and diversity }\end{array}$ & $\begin{array}{l}\text { Thinking about what } \\
\text { you already know. Reading } \\
\text { in detail. Taking notes }\end{array}$ & $\begin{array}{l}\text { Working } \\
\text { with colleagues: } \\
\text { generating ideas } \\
\text { and reporting }\end{array}$ & Language for writing \\
\hline $\begin{array}{l}\text { The world we } \\
\text { live in }\end{array}$ & $\begin{array}{l}\text { Recognising plagiarism. } \\
\text { Getting started. Identifying } \\
\text { the main ideas in a text. } \\
\text { Summarising what you have } \\
\text { read }\end{array}$ & $\begin{array}{l}\text { Reaching } \\
\text { a consensus } \\
\text { in group work }\end{array}$ & $\begin{array}{l}\text { Using paraphrases. Including } \\
\text { quotations in your writing }\end{array}$ \\
\hline
\end{tabular}


sciendo Порівняльна професійна педагогіка 9(1)/2019 Comparative Professional Pedagogy 9(1)/2019

Continued

\begin{tabular}{|l|l|l|l|}
\hline \multicolumn{1}{|c|}{1} & \multicolumn{1}{|c|}{2} & \multicolumn{1}{|c|}{3} & \multicolumn{1}{c|}{4} \\
\hline $\begin{array}{l}\text { Behaving the } \\
\text { way we do }\end{array}$ & $\begin{array}{l}\text { Organising information } \\
\text { for an essay. } \\
\text { Skimming and scanning texts. } \\
\text { Taking notes and explaining } \\
\text { what you have read }\end{array}$ & $\begin{array}{l}\text { Referring backwards } \\
\text { and forwards } \\
\text { in presentations }\end{array}$ & $\begin{array}{l}\text { Writing conclusions in } \\
\text { essays. Language for writing: } \\
\text { hedging. Giving references }\end{array}$ \\
\hline $\begin{array}{l}\text { Bringing } \\
\text { about change }\end{array}$ & $\begin{array}{l}\text { Reading critically. Finding } \\
\text { information and taking notes }\end{array}$ & $\begin{array}{l}\text { Concluding } \\
\text { your presentation }\end{array}$ & $\begin{array}{l}\text { Adding information about } \\
\text { nouns: relative clauses }\end{array}$ \\
\hline Work and & $\begin{array}{l}\text { Understanding figures } \\
\text { and tables. } \\
\text { Scanning for information. } \\
\text { Taking notes. Understanding } \\
\text { the significance of references }\end{array}$ & $\begin{array}{l}\text { Taking part } \\
\text { an tutorials } \\
\text { in discussions }\end{array}$ & $\begin{array}{l}\text { Looking at the structure } \\
\text { and content of reports }\end{array}$ \\
\hline Controversies & $\begin{array}{l}\text { Understanding the writer's } \\
\text { opinion. } \\
\text { Identifying main ideas } \\
\text { and supporting information }\end{array}$ & $\begin{array}{l}\text { Tutorials: asking } \\
\text { for and giving } \\
\text { more information }\end{array}$ & $\begin{array}{l}\text { Describing information } \\
\text { in figures and tables }\end{array}$ \\
\hline Health & $\begin{array}{l}\text { Reading for evidence. } \\
\text { Thinking about what you } \\
\text { already know. } \\
\text { Preparing for essay writing }\end{array}$ & $\begin{array}{l}\text { Summarising what } \\
\text { has been said. } \\
\text { Evaluating visual } \\
\text { aids }\end{array}$ & $\begin{array}{l}\text { Contrasting information. } \\
\text { Taking a stance: expressing } \\
\text { disagreement }\end{array}$ \\
\hline
\end{tabular}

"Source: Hewings, M. (2012). Cambridge Academic English B2 Upper Intermediate Student's Book: An Integrated Skills Course for EAP. Cambridge: Cambridge University Press. Table 2:

Suggested topics for a syllabus in Academic Engish for senior students are presented in

Table 2

Topics of Academic English to be covered in senior years of ESL students' study and skills to be developed

\begin{tabular}{|l|l|l|l|}
\hline \multicolumn{1}{|c|}{ Topics } & \multicolumn{1}{|c|}{ Reading skills } & \multicolumn{1}{c|}{$\begin{array}{c}\text { Listening and } \\
\text { speaking skills }\end{array}$} & \multicolumn{1}{c|}{ Writing skills } \\
\hline \multicolumn{1}{|c|}{1} & \multicolumn{1}{|c|}{2} & \multicolumn{1}{c|}{3} & \multicolumn{1}{c|}{4} \\
\hline $\begin{array}{l}\text { Advertising } \\
\text { and critical } \\
\text { thinking }\end{array}$ & $\begin{array}{l}\text { Reading critically. Preparing } \\
\text { to read. Note-taking. Inferring } \\
\text { relations between sentences, } \\
\text { nominalization. Reading in detail }\end{array}$ & $\begin{array}{l}\text { Pros and cons of a } \\
\text { group work. Getting } \\
\text { an opportunity to speak } \\
\text { in a group discussion }\end{array}$ & $\begin{array}{l}\text { Writing a summary. } \\
\text { In-text referencing } \\
\text { conventions }\end{array}$ \\
\hline $\begin{array}{l}\text { Innovation } \\
\text { and invention }\end{array}$ & $\begin{array}{l}\text { Lectures, note-taking } \\
\text { and follow-up reading. } \\
\text { Reading in detail }\end{array}$ & $\begin{array}{l}\text { Asking for and giving } \\
\text { clarification in group } \\
\text { work }\end{array}$ & $\begin{array}{l}\text { Writing summaries } \\
\text { from multiple sources. } \\
\text { Reference list }\end{array}$ \\
\hline Facing challenges & $\begin{array}{l}\text { Following the writer's } \\
\text { argument. Focusing and } \\
\text { elavuative adverbs }\end{array}$ & $\begin{array}{l}\text { Working with colleagus: } \\
\text { problem solving }\end{array}$ & $\begin{array}{l}\text { Understanding } \\
\text { instructions in essays } \\
\text { and other assignment. } \\
\text { Developing an argument } \\
\text { in an essay. Style } \\
\text { in academic writing }\end{array}$ \\
\hline
\end{tabular}


sciendo Порівняльна професійна педагогіка 9(1)/2019 Comparative Professional Pedagogy 9(1)/2019

Continued

\begin{tabular}{|c|c|c|c|}
\hline 1 & 2 & 3 & 4 \\
\hline $\begin{array}{l}\text { IT in education } \\
\text { and business. }\end{array}$ & $\begin{array}{l}\text { Preparing to read a research } \\
\text { article. Ckecking predictions } \\
\text { Producing slides from texts. } \\
\text { Recognizing the relatioships } \\
\text { between pieces of research. } \\
\text { Reasons for referencing } \\
\end{array}$ & $\begin{array}{l}\text { Presentimg } \\
\text { professionally. } \\
\text { Introducing } \\
\text { presentations. } \\
\text { Presentation practice }\end{array}$ & $\begin{array}{l}\text { Using evidence. } \\
\text { Writing a research: } \\
\text { a research proposal }\end{array}$ \\
\hline $\begin{array}{l}\text { Culture, science } \\
\text { and society }\end{array}$ & $\begin{array}{l}\text { Preparing to read. } \\
\text { Identifying the main points. } \\
\text { Understanding meaning in } \\
\text { context. Formal and informal } \\
\text { verbs. Evaluating websites }\end{array}$ & $\begin{array}{l}\text { Giving opinions } \\
\text { in presentations }\end{array}$ & $\begin{array}{l}\text { Using primary } \\
\text { and secondary } \\
\text { sources. Writing } \\
\text { practice. Writing } \\
\text { up research: writing } \\
\text { an introduction } \\
\end{array}$ \\
\hline $\begin{array}{l}\text { Ways of studying } \\
\text { in higher } \\
\text { education }\end{array}$ & $\begin{array}{l}\text { Reading efficiently. } \\
\text { Understanding the } \\
\text { relationships between } \\
\text { research findings }\end{array}$ & $\begin{array}{l}\text { Presenting } \\
\text { and explaining results } \\
\text { in charts }\end{array}$ & $\begin{array}{l}\text { Choosing between } \\
\text { paraphrase and } \\
\text { quotation. Quotations } \\
\text { conventions. Writing } \\
\text { up research: the } \\
\text { literature review. } \\
\text { Writing practice } \\
\end{array}$ \\
\hline $\begin{array}{l}\text { Marketing and } \\
\text { consumers }\end{array}$ & $\begin{array}{l}\text { Evaluating academic texts: } \\
\text { a book review. } \\
\text { Reading in detail }\end{array}$ & $\begin{array}{l}\text { Conclusions and } \\
\text { recommendations. } \\
\text { Presentation practice }\end{array}$ & $\begin{array}{l}\text { Organizing information } \\
\text { in sentences. Writing } \\
\text { up research: the } \\
\text { methods section }\end{array}$ \\
\hline Criminology & \begin{tabular}{|l|} 
Making predictions. \\
Understanding plagiarism
\end{tabular} & $\begin{array}{l}\text { Dealing with questions } \\
\text { in presentations. } \\
\text { Presentation practice }\end{array}$ & $\begin{array}{l}\text { Organizing } \\
\text { information in texts. } \\
\text { Writing up research: } \\
\text { the results section. } \\
\text { Writing practice }\end{array}$ \\
\hline $\begin{array}{l}\text { Families } \\
\text { and relationships }\end{array}$ & $\begin{array}{l}\text { Understanding the writer's } \\
\text { opinion. } \\
\text { Inferring the manings of } \\
\text { words. Reading in detail. } \\
\text { Understanding figures }\end{array}$ & $\begin{array}{l}\text { Your relationships } \\
\text { with your supervisor. } \\
\text { Formality and } \\
\text { politeness in arranging } \\
\text { meetings }\end{array}$ & $\begin{array}{l}\text { Writing a critique. } \\
\text { Writing up research: } \\
\text { the discussion section }\end{array}$ \\
\hline $\begin{array}{l}\text { Communicating } \\
\text { science }\end{array}$ & $\begin{array}{l}\text { Following the argument } \\
\text { in a long article }\end{array}$ & $\begin{array}{l}\text { Working with your } \\
\text { supervisor: ending a } \\
\text { meeting }\end{array}$ & $\begin{array}{l}\text { Writing practice. } \\
\text { Editing your work. } \\
\text { Writing up research: } \\
\text { an abstract }\end{array}$ \\
\hline
\end{tabular}

"Source: Hewings, M. Thaine, C. (2012). Cambridge Academic English C1 Advanced Student's Book: An Integrated Skills Course for EAP. Cambridge: Cambridge University Press.

By the end of the course, students must achieve to:

- apply strategies for reading academic texts;

- assess the relevance of information for an academic purpose;

- describe problems and cause-and-effect using academic language;

- develop academic vocabulary and vocabulary skills;

- produce effective notes from a spoken presentation; 
- collaborate with other learners by engaging in peer-to-peer feedback;

- synthesise information and use it to begin writing a short piece of academic work;

- produce a final written piece of academic work using the skills learned.

To achieve this aim four main Academic English course components are to be used: interactive seminars; practical and reflective workshops; lesson observations; assessed projects including materials development (Future Learn, 2019).

\section{CONCLUSIONS}

Thus, it has been substantiated that Academic English must be an integral component of a curriculum for ESL students' study at foreign language departments. Insufficient provision of the Academic English discipline in curricula of foreign language departments or its absence can be the main obstacle on students' way to their realization as professionals. A possible solution to the problem is to elaborate a grounded syllabus for Academic English discipline being taught throughout all the course of study. As a basis for this elaboration a course of Academic English by M. Hewings and C. Thaine (upper-intermediate and advanced levels) has been chosen. On its basis we have outlined units to be covered by the course as well as skills to be developed. Our suggested approach is to interweave Academic English into learning process throughout all the years of study. Junior years should be dedicated to Academic English needed by students for the learning process at the university and senior years should be concentrated on Academic English that can be used in their further professional activities and post-graduate studies. Recommendations as to better and more efficient teaching of the discipline have been outlined. It has been defined that by the end of the course, students must be able to apply strategies for reading academic texts; assess the relevance of information for an academic purpose; describe problems and cause-andeffect using academic language; develop academic vocabulary and vocabulary skills; produce effective notes from a spoken presentation; collaborate with other learners by engaging in peer-to-peer feedback; synthesise information and use it to begin writing a short piece of academic work; produce a final written piece of academic work using the skills learned.

The prospect of further research is more profound study of academic writing as a substantial component of ESL students' professional training and further post-graduate studies.

\section{REFERENCES}

1. Academic English (2017). Academic English: a definition. Retrieved from https://www.academic-englishuk.com/definition-of-academic-english.

2. Ferris, D. R. (2002). Treatment of error in L2 student writing. Ann Arbor, MI: University of Michigan Press.

3. Finley, T. (2014). 8 Strategies for Teaching Academic Language. Retrieved from https://www.edutopia.org/blog/8-strategies-teaching-academic-language-todd-finley.

4. FluentU (2018). 5 Tips to Successfully Teach English for Academic Purposes. Retrieved from https://www.fluentu.com/blog/educator-english/teaching-english-for-academicpurposes/.

5. Future Learn (2019). Learning English for Academic Purposes: First Steps. Retrieved from https://www.futurelearn.com/courses/learning-english-academic-purposes-first-steps.

6. Hewings, M. (2012). Cambridge Academic English B2 Upper Intermediate Student's Book: an Integrated Skills Course for EAP. Cambridge: Cambridge University Press. 
sciendo Порівняльна професійна педагогіка 9(1)/2019 Comparative Professional Pedagogy 9(1)/2019

7. Hewings, M., \& Thaine, C. (2012). Cambridge Academic English C1 Advanced Student's Book: An Integrated Skills Course for EAP. Cambridge: Cambridge University Press.

8. Morzano, R. (2001). Classroom Instruction that Works: Research-based Strategies for Increasing Student Achievement. Virginia: ASCD.

9. Rumberger, S., \& Scarcella, R. (2000). Academic English. Linguistic Minority Research Institute Newsletter, 1, 1-2. Santa Barbara:University of California.

10. Scarcella, R. (2003). Academic English: A conceptual Framework. Linguistic Minority Research Institute Newsletter, 2. Santa Barbara: University of California.

11. The Sourcebook for Teaching Science (2017). Academic Language. Retrieved from: https://www.csun.edu/science/ref/language/pact-academic-language.html.

12. The University of Newcastle (Australia) (2018). Academic English for ESL students. Retrieved from: https://www.newcastle.edu.au/future-students/uonprep-bridgingcourses/whats-in-the-program/undergraduate-bridging-courses/prepo 77.

13. University of Richmond Writing Center (2017). Writer's web: Focusing / Connecting Ideas. Retrieved from: http://writing2.richmond.edu/writing/wweb/trans1.html.

14. Williams, K. (2018). Top 10 Terms Students Need to Know to Be Successful on Standardized Tests. Retrieved from: https://www.scholastic.com/teachers/articles/teachingcontent/top-10-terms-students-need-know-be-successful-standardized-tests/.

15. Wong, F., L. \& Snow, C. (2000). What teachers need to know about language. Washington, D.C.: ERIC Clearinghouse on Language and Linguistics. 